da Gama Machado prize to MM. J. Pantel and R. de Sinéty, for their studies in spermatogenesis; the Cuvier prize to M. Charles Janet, for his anatomical and embryological researches on ants.

Medicine and Surgery.-Montyon prizes to MM. Neumann, Ch. Nicolle, Bergonié, and Tribondeau, mentions being accorded to MM. Moussu, H. Truc and P. Chavernac, $\mathrm{Ch}$. Porcher and $\mathrm{Ch}$. Hervieux, and a citation to MM. Henri Claude and Jean Camus. The Barbier prize between M. L. Launoy, for his researches on the conditions of activity of glandular cells, and M. J. Lesage, for his experimental studies on maté (Yerba maté). The Breant prize was not claimed, but from the interest of the fund a prize of 4000 francs was awarded to W. M. Haffkine, for his work on vaccination against cholera and plague, and a mention of 1000 francs to M. Louis Rénon, for his memoir on the practical treatment of pulmonary tuberculosis; the Godard prize to M. A. Pousson, for his work on the surgery of nephritis, and a very honourable mention to M. J. L. Chirié, for his studies on arterial hypertension; the Baron-Larrey prize to $M$. Niclot, for his researches on the relations between the numbers of Anopheles and cases of malaria in the Oran district, and a very honourable mention to MM. Dupard and Lepourcelet, for their contribution to the study of meat in the army; the Bellion prize to $M$. Ch. Nicolas, for his work on public and private hygiene in the Loyalty Islands; the Mège prize (interest) to M. S. J. Metalnikoff, for his researches on Galleria mellonella; the Parkin prize to M. Ad. Cartaz, for his therapeutical studies on carbon dioxide as applied to diseases of the nose and throat.

Physiology.-Montyon prizes to $M$. Charles Dhéré, for his spectrographic researches on the absorption of the ultra-violet rays by albumenoids, proteids, and their derivatives, and to M. E. Pozerski, for his contribution to the physiological study of papaine; the Philipeaux prize to MM. J. E. Abelous and E. Bardier, for their discovery of urohypertensine; the Lallemand prize between $M$. August Pettit and Gustave Roussy; the La Caze prize to M. C. Delezenne, for the whole of his researches in physiology. The Pourat prize was not awarded, and is postponed to $\mathrm{rg}$ II.

Statistics.-A Montyon prize to M. Louis de Goy, for his financial studies, M. Ausset receiving an honourable mention.

History of Science.-Binoux prizes to M. P. Duhem, for the whole of his works relating to the history of science, and M. J. B. de Toni, for his historical studies on the life and work of Italian philosophers of the fifteenth and sixteenth centuries.

General Prizes.-Berthelot medals to MM. G. Blanc, Marcel Guerbet, Jolibois, Brunel, Émile Lefranc, Paul Letellier, Maurice Perrot; the Gegner prize to M. J. H. Fabre; the Lannelongue prize to Mme. Cusco and Mme. de Nabias; the Trémont prize to $M$. Charles Fremont; the Wilde prize to $\mathrm{M}$. Joseph Vallot, for his work on Mt. Blanc; the Longchampt prize to M. Claudius Roux, for his work on the chlorosis of plants; the Saintour prize to MM. E. F. Gautier and R. Chudeau, for their scientific studies in the Sahara; the Jean Jacques Berger prize between MM. Bienvenue (3000 francs), Biette (1000 francs), Locherer (1000 francs), Thomas (rooo francs), Faillié ( 750 francs), Hervieu ( 750 francs), Chagnaud ( 750 francs), Daydé and Pillé ( $75^{\circ}$ francs), and Calmette (6000 francs). The Petit d'Ormoy prizes were not awarded. M. E. Mercadier receives the Pierson-Périn prize for his physical researches; M. Ritz and M. Lebeuf, 2000 francs each from the Leconte fund; M. Vaucheret, the prize founded by the Marquise de Laplace; and MM. Vaucheret, Hentschel, Messiah, and Courtaigne the prize founded by M. Felix Rivot.

The Bonaparte Fund.-The committee proposes the following grants from this fund for the year I909:-M. Cayeux, 4000 francs, to enable him to follow up in the United States his researches on oolitic iron-ore deposits, already commenced in France; M. Chevalier, 400o francs, to assist his explorations in tropical Africa: M. Pérez, 4000 francs, to assist in the publication of a memoir entitled "Recherches histologiques sur les Métamorphoses des Muscides"; M. Houard, 3000 francs, to enable him to travel in Corsica, Algeria, and Tumis for the purpose of collecting material; M. Berget, 2000 francs, for the NO. 2097, VOL. 82] construction of a special form of pendulum for studying the variations of gravity; M. Bernard, 2000 francs, to assist him in his photometric studies of the variations of solar radiation; M. Blaringhem, 2000 francs, to enable him to continue his experimental researches on the variation of species; M. Estanave, 2000 francs, to permit him to continue his researches on stereoscopic vision, stereoradiography, and autostereoscopy; M. Mathias, 2000 francs, to enable him to continue his researches at the Leyden cryogenic laboratory on the rectilinear diameter of liquids and on the law of corresponding states at very low temperatures.

The academy, taking advantage of the freedom accorded it under the terms of the Petit d'Ormoy foundation, has decided this year not to give this prize in the usual form, but to strike medals commemorative of the progress made in flying. Gold medals have accordingly been awarded to Louis Bleriot, Commandant Bouttieaux, Captain Crocco, Henri Farman, Captain Ferber, Henri Juilliot, Charles de Lambert, Hubert Latham, Léon Levavasseur, Col. Charles Renard and Commandant Paul Renard (one medal), Alberto Santos-Dumont, Rodolphe Soreau, Edouard Turcouf and Henri Kapferer (one medal), Léon Teisserenc de Bort, Henry de La Vaulx, Gabriel Voisin, Commandant Jules Vover, Orville Wright, Wilbur Wright and Count de Zeppelin. Also silver-gilt medals to Gustave Hermite and Georges Besançon, Louis Breguet, Léon Delagrange, Robert Esnault-Pelterie, L. Marchis, Louis Pauthan, Henri Rougier, and Victor Tatin.

\section{CLIMATOLOGICAL REPORTS.}

$T^{H E}$ director of the meteorological observatory at Chemulpo has issued the results of the observations made at the Japanese meteorological stations in Korea for each of the months January-December, 1908. The instruments and the method of observation are the same as those at the meteorological stations in Japan, and the readings, taken six times a day, are expressed in metric and centigrade measures, with monthly means and extremes. These form an important contribution to the meteorology of the Far East; their value would be much enhanced by the addition of annual summaries.

The report on rainfall registration in Mysore for 1908 shows that, except in the Shimoga (north-west) district, the amount was deficient in all parts of that important province, reaching 43 per cent. in Kolar (east). The deficiency of the fall during both monsoons was detrimental to the cultivation of ragi, which is the staple dry crop of the province. The tables for monthly, seasonal, and yearly periods have been carefully prepared by $\mathrm{Mr}$. Iyengar, as before, with diagrams and maps showing (I) the annual rainfall for 1908 , and (2) the average for $1870-1908$. The mean amount for the whole province in I908 was 29.94 inches, the average for the thirty-nine years' period being 36.79 inches. Among the heavy daily falls we note II.22 inches in Shimoga district, and 10.90 inches in Kadur district, both in the month of July.

An important memoir on the climate of Tripoli is published in the Annals of the Italian Central Meteorological Office (vol. xxx., part i.), containing the results of observations made during the years $1893^{-1907}$, at an observatcry established by the Italian Foreign Office and the Meteorological Service, and situated in lat. $32^{\circ} 54^{\prime} \mathrm{N}$., long. $13^{\circ} \mathrm{II}^{\prime} \mathrm{E}$. The mean monthly values of atmospheric pressure exhibit the greatest variability during the winter season, when the barometer is highest; the lowest readings occur during spring. The mean monthly temperatures do not show much variation from one year to another. The means of the daily maxima are $60.0^{\circ}$ in January and $86.2^{\circ}$ in August, and of the minima $46 \cdot 1^{\circ}$ in January and $72.9^{\circ}$ in August. The absolute maxima and minima were I09. $0^{\circ}$ in July and $34.5^{\circ}$ in January. The mean annual rainfall is 17.29 inches, most of which falls between October and February (14.85 inches); from June to August inclusive little or no rain falls. The memoir has been carefully prepared in considerable detail by Profs. Martinuzzi and Eredia, and is especially valuable, as comparatively little has hitherto been published on the climatology of that country. 
In the annual summary of the India Weather Review for 1908 the observations included in monthly issues are discussed in detail, and the departures of the monthly and annual means from the normal values are calculated for each element. Dr. Walker states that, on the whole, Igo8 was cooler than usual, although in April and June, both of which were dry months, the temperature was in decided excess of the normal. Excluding the hill stations, 1908 was a year of average rainfall; of the four seasons, the cold weather and south-west monsoon were more rainy than usual, while the other two periods were markedly dry. With respect to the monsoon rainfall, the character was opposite to that prevailing in the previous seven years, all of which were in defect. The most striking feature ot the vear was the heavy rainfall in the dry zone of north-west India, due to the strong monsoon currents in July and August.

The report of the Transvaal Meteorological Department, containing observations and results in the usual form for the year ended June 30,1908 , has been received. The number of rainfall stations has greatly increased, and includes those which formerly reported to the Irrigation Department. The rainfall was below the average generally; at Pretoria the deficiency amounted to $3 \mathrm{I}$ per cent. and at Johannesburg to ro per cent. Farmers suffered from want of water, but, among the compensating factors, remarkable freedom from locusts and little damage from hailstorms are mentioned. In connection with this report we may refer to interesting contributions by $\mathrm{Mr}$. Innes (director) and Mr. Wood (chief assistant) to the climatology of the Transvaal in the current number of the Journal of the Scottish Meteorological Society. Mr. Innes remarks that it is one of the sunniest climates inhabited by civilised races, the average cloudiness being about 30 per cent., and the relative humidity low. Speaking of the High Veld generally, which is at an elevation of about 4000 feet, it is warm by day and cool at night. The rainfall averages 25 to 30 inches, the number of days with rain being only about eighty-five. At places like Johannesburg ( $575^{\circ}$ feet) the cold during winter is considerable, owing more to the cold wind than to actual temperature. Over the latter (Witwatersrand) district Mr. Wood shows that the mean monthly rainfall increases with great regularity from July (O.II inch) to January ( 5.80 inches), and then diminishes to June ( 0.09 inch). The probability of heavy rainfalls ( $\mathrm{I}$ inch and above) is entirely confined to the month October-March inclusive.

The Department of Agriculture, Nairobi, has issued its fifth annual report of meteorological records in British East Africa, containing monthly rainfall values for fiftysix stations during 1908, and averages for ten years (18991908) and under at twenty-five stations. The latter show that the mean annual rainfall varied from about 16 inches ac Kismayu to 72 inches at Mumias. Meteorological summaries for 1908 are given for ten stations; so far as these show, the absolute extremes of temperature were $99^{\circ}$ at Nandi (600o feet above sea) in February, and $35^{\circ}$ ai Elmenteita (height not stated) in January.

The Weekly Weather Report issued by the Meteorological office, London, for the period ending January $x$ contains a summary of temperature, rainfall, and bright sunshine for the year 1909. From this it is seen that for the fiftytwo weeks ending January $I$ the temperature was below the averase over the entire kingdom. The rainfail was in excess of the average in all the English districts except in the south-west, but it was generally deficient in Scotland and Ireland. The largest aggregate measurement of rain is 47.12 inches, in the west of Scotland; the least amount for the year is 26.04 inches, in the east of England. The greatest excess of rain is 5.21 inches, in the south. east of England, and the greatest deficiency $6.9 \mathrm{r}$ inches, in the north of Scotland, whilst in the north of Ireland the aggregate measurement was 5.53 inches deficient. The rainy days were in excess of the average over the entire country, except in the west of Scotland and in the English Channel. The greatest excess was twenty-two days, in the east of England. The greatest number of rainy days was $\mathbf{2 5}$, in the north of Scotland, and the least I86, in the south-east of England. The duration of bright sunshine for the year was in excess of the average over the whole of the British Isles, except in the north-east of England, where there was a deficiency of forty-three hours. The greatest excess was 146 hours, in the south-east of England. The longest duration of bright sunshine was 1975 hours, in the Channel Islands, and this was followed by 1743 hours in the south-east of England. The least duration was 1157 hours, in the north of Scotland, which, however, is fortyeight hours more than the average. The mean temperature at Greenwich for 1909 is $48.9^{\circ}$, which is $1: 2^{\circ}$ below the average of the past sixty years. The highest monthly mean is $62.7^{\circ}$, in August, the lowest $37.2^{\circ}$, in February. The temperature was below the mean in everv month except in January, April, October, and December. The absolutely highest temperature was $86^{\circ}$, in August, the lowest $14^{\circ}$, in March, which gives a range of $72^{\circ}$ in the year. The temperature was above the average on 144 days, and frost occurred on sixty-five nights, fifty-two of which occurred in January, February, March, and December. The total rainfall for the year was $25.7 \mathrm{I}$ inches, which is 1.58 inches more than the average of the last sixty years. The wettest months were June, July, and March in each of which the total fall exceeded 3 inches. In all, rain fell on 186 days, December having as many as twenty-three wet days and March twenty-two. There were during the year 1637 hours of bright sunshine at Greenwich, which is $13^{8}$ hours more than the average. The sunniest month was May, with a record excess of I40 hours. Snow fell on twenty-four days and fog occurred on forty-three days during the year.

\section{EDUCATIONAL TENDENCIES IN THE} UNITED STATES.

THE first volume of the report of the U.S. Commissioner of Education for the year ended June 30, I909, has now been published, and is consequently available at an earlier date after the conclusion of the year with which it deals than any previous report. The second and concluding volume of the report is to be issued early in March next.

The present instalment, which runs to 598 pages, is prefaced by an introduction by the Commissioner, Dr. E. E. Brown, which gives a brief résumé of the more important subjects dealt with at length in the succeeding chapters. It is possible here to refer to a few only of the numerous subjects of interest discussed in the volume.

Industrial education has commanded attention in all parts of the States during the past year. The report points out that it has become increasingly evident that one of the vital elements of the problem, so far as the United States are concerned, is the question of the relation of school training to shop practice or apprenticeship. Accounts are given of several experiments which are being tried in various States. The special combination of shop practice with regular scholastic training, which was introduced two or three years ago by the University of Cincinnati, is receiving much attention, and a modification of this plan has been carried into effect in the public schools of Fitchburg, Mass. Model and practice schools have been provided for the teaching of manual arts in connection with the State normal school in Fitchburg. A cooperative course in preparation for the metal trades has been introduced into the Lewis Institute, in Chicago, for boys from sixteen to twenty years of age. Each boy in each of the two years of this course spends twenty-six weeks in the shop and twenty-four weeks in school, receiving from his employer the school tuition fee of rol. a year and $\mathrm{I} l$. a week for the time he works in the shop. The report emphasises the fact that many diverse and often opposing interests are concerned in the effort to work out an American system of industrial education. All these interests are to be given full and fair consideration, and it is being borne in mind that, to render such a systom stable and altogether American, it must be made genuinely educational.

Agricultural education has been stimulated during the year by the inquiries and the report of the Commission on Country Life, appointed by President Roosevelt. The establishment of agricultural high schools in different parts of the country goes forward steadily. Mississippi and Arkansas have made important beginnings in the establishment of such schools during the year, and Minnesota has

No. 2097, VOL. 82] 